\title{
COETZEE IN AND OUT OF CAPE TOWN
}

\author{
Imraan Coovadia \\ University of Cape Town \\ imraan.coovadia@gmail.com
}

\begin{abstract}
This paper is an attempt to see J.M. Coetzee's emigration from South Africa to Australia as a logical step within his career, and to understand Coetzee's relationship with the city and university of Cape Town. It also tries to set out the nature of Coetzee's self-assertion and self-canonization, and the interplay between Coetzee and the Coetzeean critics.

Keywords

Coetzee criticism, South African literature

About the author

Imraan Coovadia was born in Durban. He studied philosophy at Harvard College, later earning a doctorate from Yale University in English. He is the author of three novels, including most recently High Low In-Between, which won the Sunday Times Fiction Prize, and a study of V.S. Naipaul. He writes frequently for newspapers and magazines, and directs the creative writing program at the University of Cape Town.
\end{abstract}

In 2002, a year before receiving the Nobel Prize, John Maxwell Coetzee relocated from Cape Town to Adelaide, an undistinguished provincial capital in southern Australia with a population of a million and a quarter. At 61, he adopted the title of Honorary Research Fellow at the University of Adelaide, almost as unusual a choice as the destination itself. If Coetzee's presence had never been a comfortable one for the country, his departure was even more unsettling.

Why Adelaide? London had long been the first stop for well-heeled expatriates. The Committee on Social Thought, at the University of Chicago, was the place Coetzee called his intellectual home, in a slight to the University of Cape Town where he had been on the faculty for three decades. Coetzee's dreams of retirement, like the wanderer in Life $\mathcal{E}$ Times of Michael K., had once included building a house and living out his days in the Karoo, the scrub desert north of Cape Town.

Australia, on the other hand, was popular for a certain class of emigrant from South Africa with certain expectations. Australia also had beaches and sunshine and was blessed with the 
English language. The test to which Coetzee puts many of his protagonists, an encounter with importuning brown and black outsiders, would be far more difficult to pose in Australia. You can go from Johannesburg to Perth, Durban to Brisbane, Cape Town to Adelaide, and arrive in a home which never existed except in nostalgia. To choose Australia, for many white emigres, was to reject South Africa, without making any further decision about culture or language, maintaining oneself in a kind of white familiarity, a political sentiment so powerful and yet covert that, to President Barack Obama's surprise, it revived the entirely discredited Republican Party in a matter of months in 2009.

There was nobody to ascribe reasons of racial fear or solidarity to Coetzee. Even before the 2003 Nobel, his reputation in Europe and the United States was as an icon of probity, style, and rigor. He may be the most admired writer in the world. As the Time Literary Supplement put it in February 2011, "in all of his fiction, he is our best authority on suffering, our most credible literary authority on the body." Between Waiting for the Barbarians (1981) and Disgrace (1999), Coetzee has serious claims as a stylist. He is a severe and beautiful writer at the level of the sentence and the paragraph, if never equally gifted at organizing a narrative and opening the imaginative space. He is rigorous, and modernist, in the way Derrida and Emmanuel Levinas are described as such, which is to say not at all rigorous but possessing intellectual force, and an impeccably pointed manner, and a way of raising generalized but nevertheless interesting questions, about language and ethics and subjectivity, without providing the specifics of an answer.

But as to being "our best authority on suffering, our most credible literary authority on the body," there is no real case for this on the page. The alter egos in Coetzee's fiction, who equal Philip Roth's in number, have no tendency to moral self-admiration. They incline, instead, towards self-scrutiny, and even self-hatred. The assumption of Coetzee's probity, in other words, comes from elsewhere, in great part from the political frame of apartheid-era South Africa. Waiting for the Barbarians, named for the Cavafy poem and making precisely the same point about barbarian harmlessness, hangs almost entirely on its title, just as it is impossible to retitle "The Importance of Being Earnest." Barbarians could be read as a work of scrupulous metafiction, as a postmodern meditation on the relationship between power and knowledge, and also as a protest against the ideology of the small empire, borrowed from much grander empires, which the Nationalist government built at the bottom of sub-Saharan Africa. Age of Iron, about a retired classics professor, shows that Coetzee's method involves the suppression and return and suppression of feeling, while Foe, where he most closely binds literature and the theory and historiography of literature, is centered on the specter of the other, the almost absent figure of Friday who will not speak. Coetzee's more recent work, from Elizabeth Costello and Boyhood in the past decade, has been either meta-fiction without the momentum and immediacy of fiction or meta-memoir, the half- 
fictionalized autobiographies of Diary of a Bad Year and Summertime, which lack the accuracy and explanatory power of memoir. In none of these texts is there a claim to be an "authority on suffering and the body."

Writers are not saints by assumption, except at long distance. Tolstoy provoked and continues to provoke love in everyone, except in his wife. Coetzee, who lacks greatness in person, provokes grumbling instead, and equal measures of fondness and bewilderment, directed as if against an intermittently attentive patriarch. Those close enough to him to talk, but not close enough to be loyal, or not loyal enough to be loyal, offer the same round of complaints: his manners at a dinner party where he keeps completely silent, his controlling habits as a holiday companion, his treatment of women and his stated preference for the skinny ones, his painful but suppressed experiment as a parent who lost his one child, a son, to a likely suicide and the other child, a daughter, to severe mental disturbance and emotional alienation.

One of the most astute critics in Cape Town identifies Coetzee's ferocious determination as a self-canonizer. The young writer wanted to insert his own name onto the bookshelves besides Conrad and Dostoyevsky. It is good an explanation of his motivation as any, given his early and inexplicable insistence on changing his disused second name, Michael, to the equally disused Maxwell, and his subsequent retrenchment behind his initials. John Coetzee is a person, whose authority and imagination we may or may not grant from one narrative to the next, while J.M. Coetzee, like T.S. Eliot, transcends the mere test of reading. In the series of narratives and nonnarratives and fictional memoirs since Disgrace, one senses that the almost unbroken critical reception is that given to a master and to the successive installments of a new testament, rather than to a particular book which might stand or even fail on its merits. Coetzee has become a religion rather than a source of literary experience.

There are a cluster of unexpected rumors and memories of Coetzee in Cape Town, neither so venomous nor so startling as to count towards a view of a human being. One colleague at the University of Cape Town brought himself to ask Coetzee why he would attend every social gathering only to be stand so uncomfortably throughout the occasion. The same colleague remembers Coetzee as a seductive and dramatic lecturer while others found him obscure. A surprising number of the Coetzee stories involve cars and bicycles. Coetzee is said to have locked an ideological rival in the boot of his car and driven around with him for an afternoon, a revolutionary gesture in the Parisian mode, and to have punctured another colleague's tires.

One evening, in the late 1990s, the window of his own vehicle was smashed, a small act of vandalism which he interpreted as a sign from the ruling party and a warning about a future intolerant to writers and dissenters. "We have to listen to the message that is being given," Coetzee is supposed to have said about his Kristallnacht. The African National Congress, whose faults have 
more to do with corruption than mishandling intellectuals, has not as yet renewed its campaign of intimidation against writers' cars.

Coetzee's futures never come to pass. The general catastrophe caused by monopoly capitalism or police state logic or referential language or the privileging of speech over writing in the western episteme, fails to arrive despite numerous foretellings in his fiction and non-fiction. Cape Town is a good place to understand this fact. Almost nothing of the city, its life, its beauty, its specificity, and its traditions, makes it into Disgrace, much of which is set inside the municipal boundary. Michael K imagines the formerly Jewish seaside section of Sea Point as a burned out and post-apocalyptic cityscape, something like the Australia of Mad Max. Today you wander down Sea Point Promenade past three million dollar apartments, and roller skaters, and afternoon cricket games with Congolese and Nigerian players in their whites. You could ask whether Coetzee was offering a warning or something which has more the quality of a wish.

It may be too crude to hold a writer to his predictions. You can only predict a situation if you care to know it. Coetzee is said to have attended Samuel Beckett on his deathbed. One imagines the older man passing on his particular strain of imagination, claustrophobic, metaphysical, and, finally, sealed into itself. Coetzee points out that Beckett almost preceded him at SUNY Buffalo, and even at the University of Cape Town which rejected Beckett's application for a post in the Italian Department in 1937 (after losing Tolkien in English). Beckett, like Nabokov, stands just on the one side of the twentieth-century movement of writers into the academy and Coetzee squarely on the other.

Nobody ever claimed to be the prototype of Godot's Vladimir or Estragon whereas Cape Town has its fair share of people who claim to be the originals of Coetzee's not unexceptionable characters. One woman takes pride in being the inspiration for Melanie Isaacs, the student whom David Lurie harasses in Disgrace. At least two members of the faculty at the University of Cape Town, with even more pride, see in Lurie's story their own experience being prosecuted for sexual harassment. Coetzee is remembered in the English Department, where I work, for having made everybody depressed, as I was told on the day of my arrival in Rondebosch. In the convent politics of the institution, energized only by resentiment, Coetzee was a complicated colleague, gnomic, resistant, and then unexpectedly friendly to some unexpected quarter. Resentiment is the hope for overcoming turned inward, never retracted, and therefore a secret source of happiness. How could Coetzee's colleagues not be depressed by a colleague who had overcome not only them but the canon itself?

On my same day of arrival, down the hall, another professor, a Romanticist who lived with his mother into late middle age, warned me to have a latch and chain installed on my office door in case one of the students tried to murder me. I would have to pay for the latch and chain but the 
maintenance department should install it for free. Several years before a disturbed graduate student had, indeed, beaten a maths professor to death with a cane in the next building. But that was a different department. I suspected that the same fearfulness towards local humanity, and the same frugality with money as with feelings, were not difficult to discern in the now departed eminence of the English Department.

Then there are stories that Coetzee has told about himself. On graduating from the University of Cape Town he worked as a computer programmer in London before moving to the University of Texas to study linguistics. At Austin, Coetzee was in the office August 1, 1966, when sniper Charles Whitman opened fire on the campus from the tower and observation deck in the same building, killing sixteen passersby and wounding thirty two others. Policemen Houston McCoy and Ramiro Martinez found Coetzee and told him to stay under his desk where he remained, listening to the gunshots, until McCoy and Martinez returned down the corridor and set him free. As part of his dissertation he was working on a computer program to analyze Beckett's style, thus combining his interests in literature, linguistics, and new technology.

By 1970 Coetzee was a new faculty member at SUNY Buffalo when he was charged for taking part in a Vietnam War protest and therefore denied resident status in the United States. He returned to UCT as an assistant lecturer where a hostile head of English subsequently docked his already small pay because he refused to teach first year students. In 1973, although outside the United States and entirely obscure, John Coetzee was singled out for scorn in the pages of the New York Times by the critic John Leonard for his preposterous, computer-driven study of the frequency of short and long words and phrases in Beckett's literary language. Two years later, the small amount of federal funding which assisted his graduate research attracted a Golden Fleece Award, a prize created by Wisconsin Senator William Proxmire to expose the most flagrant misuses of the public purse.

There are Coetzee stories which show real wisdom, and even some flash of grace. In 1989, following Ayatollah Khomeini's fatwa against Salman Rushdie and his Satanic Verses, the Congress of South African Writers, a left-wing group, withdrew an invitation to Rushdie to come to the country. With sincerity, but no great attachment to principle, COSAW argued that it could not ensure Rushdie's safety during his visit. Nadine Gordimer was associated with the COSAW decision. At a panel assembled in Cape Town, she is reported to have said that no book in the world was worth the loss of one human life. Coetzee replied that fundamentalists were not to be trusted because they believed that there should be only one book in the world.

The Coetzee-Gordimer relationship was almost non-existent, the first associated with Cape Town and the United States, literary theory, and the heterodox, while the second was Johannesburg, social realism of the type recommended by Lukacs, and activism in concert with 
progressive groups. Gordimer, Jewish and secular, even turned down the Jerusalem Prize, in accordance with left-wing orthodoxy that she has shown throughout her career and which counts, in her favor, as the sign of love for a cause. When the same prize was offered to him on Gordimer's refusal, Coetzee turned up in Jerusalem in 1987 to collect, lending his moral probity to the Israeli occupation. Even Ian McEwan, in February 2011, had the courtesy to mention the settlements, if not the entire apparatus of state degradation in Israel and Palestine, which escaped Coetzee's attention, perhaps because it didn't lend itself to theoretical interpretation.

Later on, Gordimer made the point that the author of Disgrace showed far more sympathy for the dead dogs than for any human being. At the time it sounded like an unnecessarily sharp remark. Yet, in the decade after Disgrace, Coetzee dramatically embraced animal rights. He even made provocative comparisons between concentration camps and industrial-scale agriculture, comparisons which he advanced and retracted in the same gesture, as if he could build a new morality with thought experiments. Gordimer didn't say that the habit of loving animals, and fearing human beings, has an unsavory genealogy in the colonies and post-colonies, especially amongst English South Africans.

The fact that there were so few points of contact between Coetzee and Gordimer defined the literary scene in South Africa for three decades and was even preferable to the soupy camaraderie which prevailed in Afrikaans circles. Gordimer was close to the ever-new cadres of left-wing black and white writers, playwrights, and artists in Johannesburg. If she wasn't temperamentally suited to be a den mother, she was at least a matriarch. In recent years, as Coetzee has eclipsed his older rival as a global figure, it is good to remember that Gordimer's contributions to writing don't necessarily turn up on the page. Paradoxically, it is John Coetzee who can be friendly in person, belying his forbidding reputation, while Gordimer, in my experience, comes across as far more polite and more distant, with a Victorian correctness, if not grandness, to insulate her from the demands of such great fame. No doubt Gordimer is friendly to her friends, maternal to her children, faithful to her political comrades, but Isaac Babel's striking remark that a writer keeps a splinter of ice in the soul applies to her without qualification. In Coetzee's case, however, it's not just ice, and it's not just a splinter.

Then there are autobiographical facts which have been encoded and converted into Coetzee's novels, their subterranean presence lending passion and hypnotic feeling to such barebones thought experiments as Foe and Age of Iron. There are, for example, signs of Coetzee's lost son and daughter in his literature, perhaps in the way that Shakespeare's son Hamnet who died at the age of eleven in 1596 is remembered three years later in Hamlet. In Master of Petersburg (1994) Coetzee develops, through the figure of Dostoyevsky, the problem of a father responding to the possible suicide of his son as he might, and indeed must, have done in 1990 on the death of his own 
son. Disgrace, which offers a difficult symmetry between Lurie's harassment of a student and his daughter's rape by three black men, records Lurie's inability, as a father, to reckon with and master Lucy's incompatible sentiments.

By the 1990s, with one Booker Prize to his name, Coetzee was overseas, a visiting faculty member in Texas and Cambridge and Palo Alto, where he was more comfortable in his own skin, more than in South Africa where he had ascended to the strangely named position of Professor of General Literature at UCT. (His titles do something to indicate the difficulty of fitting a writer into an institution.) If his first sojourn in the United States ended in political difficulty and ridicule, the second proved to be much happier and especially at the University of Chicago. The Committee on Social Thought at Chicago, associated with the names of T.S. Eliot, Arendt, Hayek, Allan Bloom, and Saul Bellow, was a logical home for a writer who had, in a way that he chose not to define, turned his radicalism against the doctrines of the political Left.

It is hard to imagine the Committee coopting Nadine Gordimer, or Athol Fugard, a playwright who could stage a drama to great effect in a worker's hostel in Durban in the 1970s. Fugard and Gordimer built their work out of what used to be called life, vivid feelings, characters in unexpected situations, and sharp conflicts. Coetzee, however, is the great writer, maybe the only great writer, of the vast body of literary and cultural interpretation that we call theory. Not simply a metafictionalist, like Calvino, nor a writer like Sebald whose work demands theoretical reflection, Coetzee assembles his fiction, and even his conversation, from sections of theoretical discourse. He borrows the themes of his narratives from questions raised in contemporary theory about such matters as signification, subjectivity, and colonial subordination.

To take one example, in a written exchange of notes with the critic David Attwell which were published in the form of an interview, Coetzee rationalizes his distrust of the spoken performance: "To me, truth is related to silence, to reflection, to the practice of writing. Speech is not a fount of truth but a pale and provisional version of writing." In that personalizing opening ("to $\mathrm{me}^{\prime \prime}$ ) and the insistence of sentence rhythm ("to silence, to reflection, to the practice of writing"), Coetzee evokes an individualized wisdom derived from experience, something he has come to himself. The thought is somehow pointed, and yet obscure at bottom, abstracted and philosophical in character, and yet poignant: "speech is ... a pale and provisional version of writing." The poignancy, intimacy, and personalization are the contribution of his literary style because, of course, Coetzee is simply paraphrasing Derrida of the On Grammatology period.

A Coetzee defender, attached to his master as he would have been fifty years ago to T.S. Eliot, assumes that the novelist is self-conscious to the highest possible degree. Coetzean irony is a total fact. Therefore, when Coetzee offers a thought from Derrida as his own he is ironizing the protocols of the interview, and the conventions of the question and of the answer, and those 
of authorship, and even that of irony. This argument may even be true, as a defense, while obscuring the fact that Coetzee's narratives and essays and artificial interviews are a gigantic corpus of quotation. They resemble, in other words, The Wasteland, although instead of Sanskript scripture and genteel conversation, Coetzee borrows from Derrida, Foucault, Levinas, and many unremembered figures whose rise and fall in the theory universe is now as difficult to decipher as a page from a history of medieval scholastics.

It is one of the stranger circuits in literary history. The writer whose modernist narratives glowed out of proportion in their political context went on to make theory glow. Several generations of academics have returned the favor, discovering that a Levinassian framework might profitably be applied to Foe, a novel which seems to have been composed under the very sign of Levinas, as if Levinas were not someone whose thoughts might be contested but rather a leader of thought whose questions must be accepted and repeated in almost the style in which they are originally offered. International scholarship on Coetzee, with some exceptions, involves walking one step behind the master, collecting the allusions he scatters to Foucault or Levinas or Derrida and arranging them reverently in his honor, which is also to the honor of pure literature.

In pure literature, and pure theory, politics and history disappear behind gestures to the correct politics and the idea of historicization, and so does the existence of race which has been a perpetual embarrassment to intellectual discourse because of its crudity and biological, if not political, falsity. To a South African reader there are traces of these lingering facts in Coetzee's narratives, the State of Emergency in Waiting for the Barbarians, the likely Cape Malay identity of Melanie Isaacs in Disgrace which links her to the eighteenth-century slave trade at the Cape and the Indonesian archipelago, the Colored rather than Xhosa affiliation of Michael K. whose name links him also to Coetzee, who had once been Michael, as well as to Kafka. To an international reader, Waiting for the Barbarians is a general treatment on state power and resistance, connected not so much to Cavafy or to the Cape or to the behavior of the Special Branch under the Emergency but to Foucault and perhaps Giorgio Agamben.

By definition a classic finds many different uses in many different hands. Every classic has survived the process of decontexualization. Coetzee's case is striking for how much in his writing changes if one approaches it without the premise of context. His recent books have been more and more purified in this sense, from the Oulipo-style experiment of Diary of a Bad Year with its three independent columns of text to the game-playing in Summertime which offers a largely invented life of Coetzee to the biographical desires of his readers. His international and academic readers have, on the basis of these purified texts, made him almost the subject of a bardolatry.

In the 1980s, even in avant gardist texts like Dusklands, Coetzee's narratives staged a contest between emotional censorship, postponement, and estrangement, on the one hand, and release, 
love, and identification on the other. The momentum of many of his early and middle works lies in the repression, evasion, and then sporadic blossoming of a certain lyricism of the protagonist. Yet as the international master, in Elizabeth Costello and Summertime, Coetzee takes flight only in the games he plays with his own biography and authority. To call this vanity is a mistake because these works are too arid, and too well defended by irony and a posture of self-hatred, to submit to the voluptuous human fault of vanity. But it is the mark of someone who had purposely estranged himself from those realities which are the source of even the most abstracted forms of literature.

One sign is the complete absence of the HIV/Aids epidemic in Coetzee's writing (and the epidemic, which claims almost a thousand lives a day in South Africa, has coincided with more than half of his career). There are inassimilable biological and social and political facts, like HIV, which the author passes over in perfect silence. Instead, as the recent essay collection Inner Workings reveals, Coetzee discovers the fate of the European Jews, the topic of late twentieth-century theory in search of some absolute standard of seriousness to call its own.

Coetzee is at his best as a reader, his darkest and most penetrating, when he hears something of himself, which is often something of contemporary theory, in Svevo, or Walter Benjamin, or Robert Walser. From Paul Celan, in his Inner Workings essay, he chooses the lines "Black milk of daybreak we drink you at night/ we drink you at noon." In Sebald's stories he finds that the "world seems full of messages in some secret code" and that Sebald's characters discover "there is no cure, no salvation." He never urges you to read a book, or to entertain an idea, and advances only the sparest terms of praise and blame, beauty and repulsion. His method as an essayist, in Inner Workings, is methodical and narrow, and the final impression is one of withholding. This withholding is a key feature of what attracts and then distances the readers of his fiction and comes from so deep in his writing that one wants to interpret it as a compulsion embedded deep in his character.

Coetzee's fictional women attract and repel attention in the same way. The third banner of text in Diary of a Bad Year, for example, presents the voice of Anya, the typist of JC's essays ("a little Filipina [as we hear in the second banner written by JC] ... who thinks Kyoto is a misspelling of Tokyo"). Considered as a portrait of a twenty-nine year old woman's consciousness, it has a fair claim to be the worst section in Coetzee's writing: "As I pass him [JC], carrying the laundry basket, I make sure I waggle my behind, my delicious behind, sheathed in tight denim. If I were a man I would not be able to keep my eyes off me." And, in the midsection of each page, Coetzee's alter ego, JC, a few years older than Coetzee but also a South African novelist in possession of what seems to be a Nobel Prize, is stirred by Anya's presence into something that resembles life: "As I watched her an ache, a metaphysical ache, crept over me that I did nothing to stem."

Why is it a "metaphysical ache?" Why can't aches and pains, and wishes, be aches, 
pains, and wishes, without the elevating adverb? The axiom of his academic readers is the all encompassing quality of Coetzee's writing: any objection we pose, at the level of style or content or imaginative coherence, has been provoked and anticipated by the text. Perhaps Coetzee wants us to ask about the false idealization of a "metaphysical ache," yet JC's predicament-superfluous desire circulating in an elderly man - is one that has occupied him as a novelist since the 1980s. Yet the same predicament is more sharply struck off in Seamus Heaney's "Guttural Muse" where the poet overhears the scene at a nearby disco: "A girl in a white dress/ Was being courted out among the cars;/ As her voice swarmed and puddled into laughs/ I felt like some old pike all badged with sores/ Wanting to swim in touch with soft-mouthed life."

Coetzee writes methodically, for several and perhaps many hours a day, like Orhan Pamuk. One senses that productivity and concentration and writerly labor, in the case of both Coetzee and Pamuk, are heavily privileged over the back and forth, slow and fast, and always unreliable process of forming an imaginative work. There are almost no situations in recent years which are new to Coetzee's prose, and almost no tonal range. There is unwanted desire, and then there is only shame. For JC, in Diary of a Bad Year, as for so many of Coetzee's protagonists since his earliest narratives, shame is primal emotion and rockbottom morality: "there come times when the outrage and the shame are so great that all calculation, all prudence, is overwhelmed and one must act, that is to say, speak."

This Coetzeean shame, which is a tacit claim of moral authority, is, in my view, as threadbare by now as Flora Finching's flirtatiousness in Little Dorrit (despite the fact that she is "grown to be very broad, and short of breath"). It is not just shame which attracts Coetzee but also the long-held position of the shamer. Kafka ends The Trial with "the hands of one of the gentlemen ... laid on K.'s throat, while the other pushed the knife deep into his heart and twisted it there, twice. As his eyesight failed, K. saw the two gentlemen cheek by cheek, close in front of his face, watching the result. 'Like a dog!' he said, it was as if the shame of it should outlive him." I imagine Coetzee reading this conclusion and identifying at once with $\mathrm{K}$. and with the two gentlemen who sear shame into their victim.

In February 2011, Coetzee returned to Cape Town, visiting his not insubstantial number of friends who are often men and women of the softest possible manner, and perhaps also his daughter. The chair of the English Department, a woman who has spent her entire intellectual life on the enigma of Coetzee, ran into the man for the first time in the university parking lot. Meanwhile the same theories of his emigration did the rounds as before, as if to reconcile us to his departure. None of these theories make him come out well. Supposedly Coetzee, an ardent cyclist, couldn't cycle anymore in Cape Town because it had become too unsafe. Supposedly he wanted better medical care in Australia than was available in South Africa. Supposedly he had been 
offended by the government's criticism of Disgrace, a novel in which a white woman is raped by three black attackers and prepares herself to marry one of them. It was true that the government and others criticized the racial stereotyping in Disgrace, not to say the suggestion that guilty white South Africans offer their daughters to be raped as part of their historical redemption. But it is a tender conscience that can survive racial tyranny, censorship, and near civil war, only to succumb to Thabo Mbeki's literary criticism.

The Disgrace controversy may have had nothing to do with Coetzee's departure but, inside South Africa, for the first time, there were conservatives who sensed a new if complicated friend. The journalist Patrick Laurence, in an article promoted by the free market Helen Suzman Foundation, praised Disgrace for speaking the simple truth about "the recurring and brutal attacks on farming folk by marauding intruders, in which most of the victims are white and the assailants almost invariably black. Coetzee's dramatis personae reflect that coloration. He does not invent it." Laurence diagnosed Disgrace's "deeper context of history and historical retribution" which white South Africans must now endure. There is a problem of farm murder in South Africa, as Laurence suggests, accentuated by the great revival of white fear and racial self pity. Since 1994, one white farmer has been murdered about every five days. In this nation of fifty million, about fifty people, mostly poor and mostly black, are murdered each and every day.

Coetzee's companion, the feminist academic Dorothy Driver who went with him to Adelaide, has her own theory of the emigration. As she has been known to say, "John and I are too tender for this country." It may even be a genuinely held reason. In the essay on Gordimer in Inner Workings, another installment in the non-dialogue between the two Nobel Laureates, Coetzee observes one of Gordimer's characters departing to Europe because she is "tired of South Africa ... tired of the daily demands that a country with a centuries-long history of exploitation and violence ... makes upon the moral conscience." One might prefer, for reasons of safety or opportunity or culture or exhaustion, to keep poverty and violence and the other fruits of long exploitation at a distance, but to protect one's "moral conscience"? Maybe there is some other form of conscience, and shame, less delicate to the touch of life.

In the end it wasn't enough to leave the new South Africa as Saul Bellow left Chicago behind, or Tolstoy fled to the train station, or Shakespeare left London, for reasons which are identifiably human. There had to be a mystery to Coetzee's departure, and within the mystery an absence, and within the absence a problem of epistemology, as if Churchill's description of Stalinist Russia as "a riddle, wrapped in a mystery, inside an enigma" were a principle to speak by, and live by, instead of a place you would rather avoid. Thus, as Coetzee announced in the manner of a man reasonably protecting his privacy, "leaving a country is, in some respects, like the break-up of a marriage. It is an intimate matter." To such intimate matters, of course, there are no solutions and 
no defensible arguments, only the metaphysical unknowability which comes between souls. And we can add one other possibility. By writing Disgrace, which assigns the role of the newly oppressed to the former oppressor, and by choosing Adelaide over Cape Town, John Coetzee did as much, and in my view much more, to undermine the morale of white South Africans trying to find an accommodation with the majority than he ever did to undermine their pre-1994 oligarchy.

In 2006, despite the intimacy of his emigration, J.M. Coetzee even became the centerpiece of a campaign to convert Australian residents into full-blown citizens. His words at the ceremony organized to celebrate his taking on citizenship were widely distributed in Australian newspapers. They could not but be overheard as a firm contrast to his former country: "I was attracted," he declared, "by the free and generous spirit of the people, by the beauty of the land itself, and - when I first saw Adelaide - by the grace of the city that I now have the honor to call my home." Australia, unlike South Africa, was free and generous, beautiful and gracious, but it also brought new forms of the sins and responsibilities Coetzee relishes: "One of the more intangible of those duties and responsibilities [of a new citizen] is no matter what one's birth and background, to accept the historical past of the new country as one's own." Maybe, in Australia, he will even find new Holocausts.

By 2010 at least one of Coetzee's hosts (so "free and generous in spirit") had tired somewhat of his presence. David Foster, a 66-year-old Australian novelist, won the Patrick White Award for lifetime achievement and used the occasion to ask "what Patrick would have said of an individual who, having received the Nobel Prize and two Booker Prizes, to a value of around $\$ 1.5$ million, and who so far from setting anything aside for the benefit of his less illustrious colleagues continues to put his hand up for every literary prize on offer? Well, some people got no class." Foster even suggested that Coetzee had put his work up for so obscure a prize as the Randwick City Council Award for Literature.

Foster's accusation was so bizarre if colorfully worded ("some people got no class") that I checked. Randwick City Council, a local government unit in the eastern region of Sydney, reported the entry of "more than 100 works of fiction since the Randwick Award for Literature opened in April, keeping the four judges extremely busy for weeks." Shortlisted for the $\$ 10,000$ prize were Siddon Rock, by Glenda Guest, The Household Guide to Dying, by Debra Adelaide, Parrot and Olivier, by Peter Carey, and Summertime, by J.M. Coetzee, which had been shortlisted for the Booker Prize and named best Australian novel of the year at the New South Wales Premier's Literary Awards. Peter Carey won the inaugural Randwick Award.

As it happens, John Coetzee was the only writing teacher I ever had, in 1991 at Harvard. His only useful advice, which may be the only useful advice one can give, was to offer his own example as a writer. He wrote every day, for four hours, and in the morning. He wore an inexpensive digital 
watch, ordinary clothes, and, in general, seemed much happier and friendlier in Cambridge than, by most accounts, he ever was in Cape Town. You could even tease him, if you weren't as careful as Americans are inclined to be with their superiors, and he would respond.

It seems unfair, in retrospect, to remember the speech with which he received the Jerusalem Prize in 1987. He noted, without saying a word about the masters of the land around him, that "at the heart of the unfreedom of the hereditary masters of South Africa is a failure of love. To be blunt: their love is not enough today and has not been enough since they arrived on the continent; furthermore, their talk, their excessive talk, about how they love South Africa has consistently been directed toward the land, that is, toward what is least likely to respond to love: mountains and deserts, birds and animals and flowers."

On the day that Nadine Gordimer won the Nobel Prize in 1991, in all probability excluding Coetzee from this ultimate form of canonization, I went to see him in his office to complain. He was sitting in front of an enormous computer, which he had brought from Cape Town and which he was pretending was a laptop. He was in a contemplative mood, but not necessarily unhappy about Gordimer's success. "When we live in the same country," he explained, "we see each other's faults." 